\title{
THE PROBLEM OF EQUILIBRIUM IN THE PANJI STORY: A TZVETAN TODOROV'S NARRATOLOGY PERSPECTIVE
}

\author{
Yoseph Yapi Taum \\ Sanata Dharma University, Indonesia \\ yosephyapi@usd.ac.id \\ DOI: https://doi.org/10.24071/ijhs.2018.020110 \\ Received 5 July 2018; revised 3 August 2018; accepted 20 August 2018
}

\begin{abstract}
Narrative is understood as the record of human activities which relate strongly to a cultural matrix. Narrative, in terms of story or story telling, is representative of factual and fictional achievement placed in a chronological or causal order. Therefore, narrative and narratology have an important function in understanding cultural activities. Some structuralist scholars, especialy those living during 19601980, created a special theory on narratology. There are four specialists of narratology; they are: Vladimir Propp, Claude Levi-Strauss, Tvsetan Todorov, and A. J. Greimas. They claimed the same perspective, that all narrative (such as folktale, myth, and legend) in fact share the same fundamental structure (i.e grammar, syntactical structure, semantics axes, actantial structure, or logical structure). Panji Story is one of Indonesian heritage stories popular during the rule of Madjapahit Kingdom. The narratives were transmitted into folktales, oral literature, written literature, hikayat, or engraved as the reliefs at ancient temples. The narrative which was originated from Singasari Kingdom was so pervasive in East Javanese culture, as it created a Panji Culture (Nurcahyo, 2016). The spread of the narratives was so extensive, reaching Bali, Nusa Tenggara, Sumatra, Borneo, Papua, and to neighbouring countries such as Malaysia, Thailand, Cambodia, Laos, and Myanmar. This paper aims at revealing narrative sequences of Panji Narratives in line with Todorov's narrative theory, especially in relation to his narratology theory of equilibrium. Todorov's equilibrium gets a new perspective and meaning.
\end{abstract}

Keywords: narratology, Panji narratives, equilibrium, disruption, realization, repair, restoration

\section{Introduction}

Through long and arduous struggle, the Panji script was officially recognized by UNESCO as one of the memories of the world (MOW), in October 2017. In February 2017, the nomination proposal was signed by four countries, namely: Indonesia, Malaysia, Cambodia, and the Netherlands. In the proposal, Indonesia included 76 Panji manuscripts; Malaysia attached 7 Panji manuscripts; Cambodia 
1 Panji manuscript; and Leiden University attached 252 Panji manuscripts (Agung, 2018). As noted by Prasetya (2014), Panji is a typical form of Indonesian creativity popular during the Majapahit kingdom in East Java. One thing is certain that the manuscript or oral version of Panji story created at that time is not based on the Indian literature.

The Panji story essentially contains the Javanese romance very popular in the Majapahit era (1300-1500 AD). The depiction of Panji story was also seen in the reliefs of the Panji story at Kendalisodo Temple, Mirigambar Temple in Tulungagung Regency, Yudha Temple on the slope of Penanggungan Mount, and especially Panataran Temple in Blitar Regency. Kieven (2014) assumed that the figure with a hat carved on the temple's reliefs was Panji. The Panji storyis written in various versions of literature. These stories tell of the engagement of Putra Panji (Inu) from the Kingdom of Jenggala / Kahuripan with Putri Candrakirana (Sekartaji) from the kingdom of Daha/Kediri. After being separated, the two lovers searched for each other. They are eventually reunited after wandering around and overcoming many obstacles. These three elements - separation, mutual searching, and reunion - are characteristics of all versions of the Panji story.

During the 177 years of power, the Kingdom of Kediri (1045-1222) contributed to the color of the civilization in the archipelago. In its golden age, the reign of Kediri Kingdom covered a relatively extensive area. The expansive spread of the Panji story from Kediri kingdom in East Java to other places across the Archipelago is a proof that the Kingdom covered a very extensive area. Besides gaining popularity in Java, the Panji story was also known in Bali, Nusa Tenggara, Sumatra, Kalimantan, and Papua. It even spread to Malaysia, Thailand, Cambodia, Laos, and Myanmar (Nurcahyo, 2016: 21-22). The Panji story is not only inherited through oral media (fairy tales) but also written media (saga), performing arts (wayang beber), and enshrined in temple reliefs. Despite its status as the world heritage, the Panji story is not understood and studied intensively or extensively, especially by the cultural owners of the story. It is time for the Panji story to be reviewed and appreciated more deeply by younger generation.

Questions arise, such as "Why is the Panji story so famous? What are the characteristics of the story compared to other stories? What is the meaning of Panji story?" This paper has two purposes. First, it aims to examine the narrative structure of the Panji story and reveal its meaning, both the surface and deeper meaning. Second, it aims to understand the basic structure of various Panji stories by using Tzvetan Todorov's structuralism narratology.

\section{Theory}

Narratology is a branch of structuralism that studies the narrative structure and how the structure influences the readers' perception. Narratology comes from Latin words narratio and logos. Narratio means a narrative, words, story, saga; whereas $\log o$ means science. Narratology is an attempt to study the nature of a 'story' as a concept and as a cultural practice. So, narratology is a systematic study of stories.

Narratology is also called a narrative discourse theory. Both narratology and narrative discourse theory are interpreted as a set of concepts about story and storytelling. Narratology develops on the basis of linguistic analogies, such as 
syntactic models, as in the relationship between a subject, a predicate, and an object.

Tvzetan Todorov (1939-2017) is a prominent Bulgarian-French structuralist literary critic who studies the theory of narratology. He is also known as a philosopher, historian, anthropologist, and sociologist who is influential in these fields of science. Todorov uses the term narratologie to refer to structural analysis of parts of the story to reveal the functions and relations of these parts. He defines the story as "what is told" (what is narrated). The story being told is usually a chronological sequence of themes, motives, and plot lines. The plot presents the logical and causal relationship of a story. Discourse is used to describe stylistic choices that determine how a narrative text or performance is presented to the readers or audience (Richardson, 2017).

Todorov asserted that all the stories begin from the 'equilibrium' situation, a balanced state in which opposing forces are not in confrontation. This situation was then disrupted by "an event that changes the peaceful state." Other events then lead to the second 'equilibrium' situation.

As Richardson (2017) illustrates, there are five stages of narrative development that are shown in units of text meaning. The five stages are as follows: (1) a state of equilibrium, a condition that should occur; (2) Stage of disruption to the order; (3) Stage of realization (recognition) of disruption; (4) Phase of efforts to repair damage that occurs; and (5) the new equilibrium stage, a state of restoring the balanced condition. These five stages do not occur in a linear line but in a cycle (circle). If described, Todorov's narrative cycle is seen in the following figure 1 .

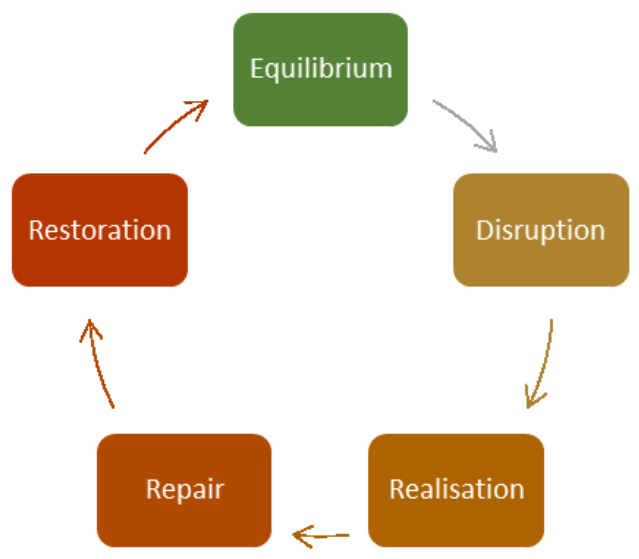

Figure 1 of Todorov's Narrative Cycle

Narration is driven by the urge to create balance. The initial balance and the final balance in the cycle are not the same. According to Todorov, narration always involves transformation. The characters of the stories and their situation are transformed through the development of disruption. Disruption often occurs outside local social norms, for example murder and creation of fear from which a character who solves the mystery will appear (Todorov, 1971).

\section{Theory Application}

The Panji story is not only documented in fairy tales. The study conducted by Nurcahyo (2016) on the tradition of the Panji story confirms that the appropriate 
term to refer to all information relating to the Panji story is the Panji Culture. The Panji culture is a set of artifacts, sociofacts and mentifacts related to the Panji story. In the Panji culture, the Panji stories are found in four genres, namely Hikayat Panji (Panji Saga), Dongeng Panji (A Tale of Panji), Sastra Panji (Panji Literature), and Seni Pertunjukan Panji (Performing Arts). There are several documented media for the Panji story, namely oral media, ancient texts, written literature, temple reliefs, and performing arts.

Through oral media, we know the Tales of Panji, such as Keong Mas, Timun Mas (the East Javanese version), Ande-ande Lumut, Panji Laras, and Golek Kencana. Through the media of written literature, we know Sastra Panji (Panji Literature), Panji Mordaningkung, Panji Megatkung, Panji Chekel Waningpati, Panji Narawangsa, Panji Jayengtilem, Panji Wulung, Serat Panji, Serat Panji Dadap, Wangbang Wideya, and Panji Raras. From the inherited forms of saga, we know Hikayat Panji Semirang, Hikayat Panji Anggraeni or Hikayat Kudawenangpati, and Hikayat Panji Jayakusuma. There are many performing Arts related to the Panji Story. Among them are Wayang Topeng (Malang), Wayang Beber (Pacitan), Wayang Timplong (Nganjuk), Wayang Gedog (Malang), Wayang Krucil (Malang), Wayang Thengul (Bojonegoro), Kethek Ogleng (Pacitan, Wonogiri), Jaranan (Trenggalek, Tulungagung), Reyog Ponorogo, Lutung Kasarung (Sunda), Legong Dance, Drama Gong (Bali).

The following discussion involves five texts, namely (1) Hikayat Panji Semirang, (2) Hikayat Panji Anggraeni; (3) Keong Mas story; (4) Ande Ande Lumut story; and (5) The Panji Story in Temple Reliefs.

\section{Hikayat Panji Semirang}

Hikayat Panji Semirang is a romantic love story between Dewi Sekartaji and Raden Inu Kertapati that is full of obstacles and challenges. As a result of the jealousy of his half-sister, Galuh Ajeng, Dewi Sekartaji shaves off her hair, flees and disguises herself as a man. At first she calls herself Panji Semirang, then changes her name to Gambuh Warga Asmara. The disguise of Dewi Sekartaji ends when Raden Inu Kertapati catches her cuddling the doll given by Inu Kertapati.

The following are the narrative units which are grouped based on Todorov's narrative perspective:

1. Dewi Sekartaji or Candrakirana lives happily with her father in the Royal Palace of Daha (Kediri).

2. From his concubine, King Daha begets a daughter named Galuh Ajeng, who is envious and pampered by her father. One day, Raden Inu Kertapati sends two dolls. The golden doll is wrapped in rags and the silver doll is wrapped in silk. Ajeng chooses the silk-wrapped doll. Upon learning that she gets a silver doll, she wants to trade it with Candrakirana's doll. Candrakirana does not want to trade it. Her father shaves off her head to make Candrakirana look like a man. She leaves the palace and builds herself a royal palace. She disguises herself as a man named Panji Semirang.

3. Raden Inu Kertapati realizes that Panji Semirang and later Gambuh Warga Asmara is actually Dewi Candrakirana. 
4. Inu Kertapati finds Dewi Candrakirana cuddling the golden doll he sends her as a gift.

5. Inu Kertapati and Dewi Candrakirana get married and live happily ever after in the royal palace.

\section{Hikayat Panji Anggraeni}

Hikayat Panji Anggraeni is a touching romantic love story. The story, abound in metaphors and symbols of romance, tells about the romance between Raden Inu Kertapati and Dewi Sekartaji, the reincarnation of his dead lover, Dewi Anggraeni. Although he is arranged to marry Dewi Sekartaji, Inu Kertapati falls madly in love with Dewi Anggraeni. For this, Dewi Anggraeni is murdered. Her beauty reincarnates in the body of Dewi Sekartaji and makes her more beautiful. Dewi Sekartaji is named Dewi Galuh Candra Kirana (the light of the moon).

The following are the narrative units of the Panji Anggraeni story based on Todorov's narratology formation:

1. Raden Inu Kertapati of Jenggala Kingdom is arranged to marry Dewi Sekartaji (Candrakirana). They both know this.

2. However, Raden Inu Kertapati falls deeply in love with Dewi Anggraeni, the daughter of Jenggala prime minister. Upon learning this, the King of Kediri is furious. Inu Kertapati's father hopes that Dewi Anggraeni will be the second wife. But Inu Kertapati does not marry anyone if his wish to marry Dewi Anggraeni is forbidden. Dewi Anggraeni is killed. Upon learning Dewi Anggraeni's death, Inu Kertapati is devastated and acts like a crazy man. He carries Dewi Anggraeni's dead body anywhere.

3. Raden Inu Kertapati realizes that Dewi Anggraeni is dead. He cremates her body. After that, Inu Kertapati wanders in the disguise of a man named Kudaweningpati.

4. When he walks in the garden of soka (geranium) flowers during the full moon, he sees Dewi Anggraeni's spirit fly to the moon from the blossoms of the soka flowers. The gods tell him that Anggraeni has become the moonlight shining upon Sekartaji. Sekartaji's beauty doubles and she gets a new name: Dewi Galuh Candra Kirana (moonlight).

5. Inu Kertapati realizes the resemblance between Candra Kirana and Dewi Anggraeni. He falls in love with Candra Kirana, gets married and they live happily ever after in the royal palace.

\section{Keong Emas}

Like Ande Ande Lumut, Keong Emas, or literally Golden Conch, is another popular folklore in Indonesia. The Keong Emas Imax Theatre, a giant snailshaped theater building for a special high-tech movie show and performances, was named after Keong Emas. The theater building was founded on the initiative of Mrs. Tien Soeharto, the late First Lady of the second president of Indonesia, Soeharto, and was inaugurated on April 20, 1984. The story of Keong Emas is a romantic love story between Raden Inu Kertapati and Dewi Candrakirana. The challenge they face this time is Dewi Galuh's jealousy. One person's happiness can mean another person's misfortune" (Todorov, 1971). This love triangle triggers the development of Keong Emas storyline. 
The following section describes the narrative units of the Keong Emas story in Todorov's narratology perspective.

1. King Kertamarta from the Kingdom of Daha has two daughters: Dewi Galuh and Candrakirana. Dewi Cadrakirana is betrothed to Raden Inu Kertapati of the Kingdom of Jenggala.

2. Dewi Galuh feels jealous and envious to Candrakirana. Dewi Galuh asks for the enchantress' assistance to cast a spell on Candrakirana. The enchantress transforms Candrakirana into a golden conch and throws it to the sea. The magic will only be broken after she meets her fiancé.

3. An elderly woman catches fish and the golden conch. She puts it in a water vessel. Strange things happen. Food abounds and her house is always clean and neat. Who has done all of these things? Intrigued, the elderly woman peeks to see what is going on.

4. Keong Emas introduces herself as the princess of Daha Kingdom who is bewitched and turned into a golden sconch by a wicked enchantress. When it happens, Raden Inu Kertapati ventures out in search for Candrakirana. The Wicked Enchantress disguises herself as a crow and shows him the wrong direction. Fortunately, an elderly man helps him find the right way. Raden Inu Kertapati continues to the village of Dadapan. When he sees a girl cooking, the magic disappears.

5. Raden Inu Kertapati marries Dewi Candrakirana. The elderly woman from Desa Dadapan is brought to live in the palace.

\section{Dongeng Ande Ande Lumut}

The story of Ande Ande Lumut has been studied using the Levi Strauss Structuralism approach by Taum (2011: 117-190). In the study, it was revealed that the cycle in the Panji story was closely related to the twin kingdoms of Kediri and Jenggala which were originally one kingdom called Kahuripan founded by King Airlangga. Disputes and civil wars between these two kingdoms constantly broke out. Taum concluded that the Story of Ande Ande Lumut implicitly projects the desires of the two twin kingdoms, Jenggala and Kediri, to live harmoniously and peacefully as envisioned by King Airlangga.

The following section describes the narrative units in Todorov's narrative theory.

(1) Once upon a time, in East Java, Indonesia, there are two twin kingdoms, Jenggala Kingdom led by King Jayengnegara, and Kediri Kingdom led by King Jayengrana. It is told that both kingdoms used to be the realms of one kingdom called Kahuripan. According to the King Airlangga's last word before he died, the two kingdoms must be reunited through a bond of a marriage to avoid a civil war. Finally, Panji Asmarabangun (the heir of Jayengnegara) is betrothed to Sekartaji (the daughter of Jayengrana). They live happily ever after.

(2) One day, Jenggala Kingdom is attacked by an enemy. In the midst of a fierce battle, Dewi Sekartaji escapes battle and hides in a village far away from Jenggala Kingdom. For her own safety, she disguises herself as a village girl and serves a wealthy widow, named Nyai Intan. Nyai Intan has three beautiful and flirtatious daughters. The eldest is Kleting Abang, the middle is Kleting Ijo, and the youngest is Kleting Biru. Dewi Sekartaji is adopted by Nyai Intan and given a name Kleting Kuning. In the 
Widow's household, Kleting Kuning must do all the houseworks, such as cooking, washing, and cleaning the house. Nyai Intan often yells at her and her three other siblings treat her like a slave. In fact, the Widow only allows her to eat once a day.

(3) Meanwhile, in Jenggala Kingdom, Panji Asmarabangun and his troop succeed in defeating the enemy's troop. However, he is saddened because his wife has left the Jenggala palace and no one knows her whereabouts. After the peace and security resume in Jenggala, the Prince decides to find his wife by disguising himself as Ande-ande Lumut.

(4) Ande-ande Lumut announces a contest of finding a perfect wife. Kleting Kuning is the only one that can win his heart. The other girls are rejected by the Prince because the girls have let themselves be kissed by cunning Yuyu Kangkang. Kleting Kuning is confused because she has not found her husband. However, after Ande-ande Lumut removes his disguise and reveals that he is Panji Asmarabangun, Kleting Kuning is taken aback. Using the magic whip given by the stork, Kleting Kuning transforms herself into the most beautiful princess anyone has ever seen.

(5) Panji Asmarabangun finds out in disbelief that Kleting Kuning is indeed his own wife, Dewi Sekartaji. Finally, the enamored husband and wife are reunited and they live happily ever after. They move to live in the Jenggala palace, while Nyai Intan and her three daughters return to their village, disappointed and disgraced.

\section{The Panji story in the Temple's reliefs}

Based on the research by Kieven (2014), it is revealed that the reliefs in Panataran Temple show repeating patterns of situations. When streamlined, the reliefs retell an interesting spiritual pilgrimage. The five phases in Todorov's narratology framework can be arranged in the following sequence:

(1) Yearning and Separation: a man and a woman sit in a typical pose yearning for love.

(2) The journey of a man wearing a hat and his aides or kadeyan Kertolo and Jurudeh.

(3) The encounter with a hermit.

(4) Crossing a body of water.

(5) The union of a man and a woman in an intertwining position suggesting a sexual intercourse.

Compared to the Panji story, the narrative sequence of the temple reliefs is different. The third (3) element "the union of a man and a woman" generally occurs at the end of a narrative journey. In Kieven's notes (2014), the (1), (2), and (3) elements are important elements in a Panji literature. The strikingly different and most accentuated visual media in the reliefs are depicted in elements (4) and (5). Element (4) - the encounter with a hermit - symbolizes the teaching of dharma or high spiritual knowledge. Element (5) - crossing a body of water symbolizes purification and movement from one stage of spiritual awakening to the higher level. Finally, it will end in the understanding of the Highest Wisdom or sangkan paraning dumadi - the beginning of all things (The Supreme).

\section{Hidden Allusion}

Kieven's conclusion (2014) on the symbols of spiritual purification and movement from one stage of religious knowledge to the higher stages is aligned 
with Kuntara Widyamartana (1990:8) in his study on Arjunawiwaha. According to Widyamartana, Arjunawiwaha essentially suggests that the marriage between Arjuna and his wives (such as Drupadi, Ulupi, Citrasena, Subadra) has a religious and philosophical background of Tantric Hinduism and Buddhism. Kakawin essentially a symbol or an allegory (Robson in Widyamartana, 1990:8). Thus, an allegory or hidden allusion must be revealed in the Kakawin.

It is predicted that the Panji story has a hidden allusion. This allusion becomes clear when the temple reliefs telling the Panji story are studied, as conducted by Kieven (2014). The close relationship between the Panji story and Kakawin Arjunawiwaha can be seen in the context and locus of the two stories. According to Robson, Arjunawiwaha presents the life of Airlangga and contains the genealogy of Airlangga (Widyamartana, 1990:8). Meanwhile, the Panji story occurs when Airlangga divides Singosari into two small kingdoms, Jenggala and Kediri.

The theme 'yearning and union', as depicted in elements (1) and (3), is understood as two amorous (kama) situations as important experiences in the esoteric concept of "love during absence" and "love in consummation" (Supomo, in Kieven, 2014). This theme pervades throughout the story of Kakawin Arjunawiwaha.

Table 2 below concludes the discussion of Hikayat Panji Semirang, Hikayat Panji Anggraeni, Dongeng Keong Emas, and Dongeng Ande-ande Lumut, and the Panji story in Todorov's narratology perspective.

Table 2. The Panji story in Todorov's Narratology

\begin{tabular}{|c|c|c|c|c|c|}
\hline & Equilibrium & Disruption & Realisation & Repair & $\begin{array}{l}\text { Restoration } \\
\text { (Equilibrium) }\end{array}$ \\
\hline 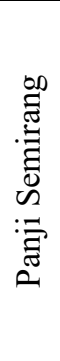 & $\begin{array}{l}\text { Dewi Sekartaji } \\
\text { lives happily with } \\
\text { her father in the } \\
\text { palace of Daha } \\
\text { (Kediri) } \\
\text { Kingdom. }\end{array}$ & $\begin{array}{l}\text { From his } \\
\text { concubine, the } \\
\text { King of Daha } \\
\text { begets a } \\
\text { daughter, named } \\
\text { Galuh Ajeng, a } \\
\text { jealous and } \\
\text { spoiled girl. }\end{array}$ & $\begin{array}{l}\text { Raden Inu } \\
\text { Kertapati } \\
\text { realizes that } \\
\text { Panji Semirang } \\
\text { and later } \\
\text { Gambuh Warga } \\
\text { Asmara is } \\
\text { actually Dewi } \\
\text { Candrakirana. }\end{array}$ & $\begin{array}{l}\text { Inu Kertapati } \\
\text { finds Dewi } \\
\text { Candrakirana } \\
\text { cuddling the } \\
\text { doll that } \\
\text { Raden Inu } \\
\text { Kertapati has } \\
\text { given her. }\end{array}$ & $\begin{array}{l}\text { The marriage } \\
\text { of Inu } \\
\text { Kertapati and } \\
\text { Dewi } \\
\text { Candrakirana }\end{array}$ \\
\hline 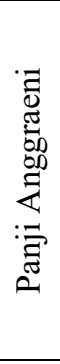 & $\begin{array}{l}\text { Raden Inu from } \\
\text { Jenggala kingdom } \\
\text { is arranged to } \\
\text { marry Dewi } \\
\text { Sekartaji. They } \\
\text { know that they } \\
\text { will marry each } \\
\text { other. }\end{array}$ & $\begin{array}{l}\text { Raden Inu falls } \\
\text { madly in love } \\
\text { with Dewi } \\
\text { Anggraeni, the } \\
\text { daughter of the } \\
\text { prime minister } \\
\text { of Jenggala. }\end{array}$ & $\begin{array}{lr}\text { Raden } & \text { Inu } \\
\text { realizes } & \text { that } \\
\text { Anggraeni } & \text { is } \\
\text { dead, and } & \text { he } \\
\text { wanders } & \\
\text { aimlessly } & \\
\text { disguising } & \\
\text { himself } & \text { as } \\
\text { Kudaweningpati. }\end{array}$ & $\begin{array}{l}\text { The spirit of } \\
\text { Dewi } \\
\text { Anggraeni } \\
\text { reincarnates } \\
\text { in Dewi } \\
\text { Sekartaji. }\end{array}$ & $\begin{array}{l}\text { Inu marries } \\
\text { Dewi Sekartaji } \\
\text { who has been } \\
\text { transformed } \\
\text { into Dewi } \\
\text { Candrakirana. }\end{array}$ \\
\hline
\end{tabular}




\begin{tabular}{|c|c|c|c|c|c|}
\hline 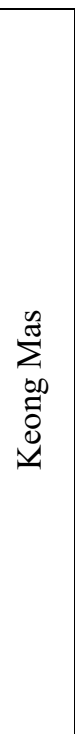 & $\begin{array}{l}\text { King Kertamarta } \\
\text { from Daha } \\
\text { Kingdom has two } \\
\text { daughters: Dewi } \\
\text { Galuh and } \\
\text { Candrakirana. } \\
\text { Dewi Cadrakirana } \\
\text { is engaged to } \\
\text { Raden Inu } \\
\text { Kertapati from } \\
\text { Jenggala } \\
\text { Kingdom. }\end{array}$ & $\begin{array}{l}\text { Dewi Galuh is } \\
\text { jealous and } \\
\text { envious. An } \\
\text { enchantress } \\
\text { transforms Dewi } \\
\text { Candrakirana } \\
\text { into a golden } \\
\text { conch (literal } \\
\text { meaning of } \\
\text { Keong Emas) } \\
\text { and throws it to } \\
\text { the sea. The } \\
\text { spell will only } \\
\text { be broken after } \\
\text { Dewi } \\
\text { Chandrakirana } \\
\text { reunites with } \\
\text { her fiancé. }\end{array}$ & $\begin{array}{l}\text { An elderly } \\
\text { widow finds a } \\
\text { golden conch. } \\
\text { After that, food } \\
\text { abounds in her } \\
\text { house. Keong } \\
\text { Emas shows } \\
\text { herself as a } \\
\text { princess of Daha } \\
\text { Kingdom who is } \\
\text { transformed into } \\
\text { a golden conch } \\
\text { by an } \\
\text { enchantress' } \\
\text { spell. }\end{array}$ & $\begin{array}{l}\text { Raden Inu } \\
\text { ventures out } \\
\text { in search for } \\
\text { Candrakirana } \\
\text { in disguise. } \\
\text { When he sees } \\
\text { a girl } \\
\text { cooking, the } \\
\text { enchantress's } \\
\text { spell is lifted } \\
\text { and the girl is } \\
\text { freed. }\end{array}$ & $\begin{array}{l}\text { Raden Inu } \\
\text { Kertapati } \\
\text { marries Dewi } \\
\text { Candrakirana. } \\
\text { The elderly } \\
\text { widow of } \\
\text { Dadapan is } \\
\text { brought to live } \\
\text { in the palace. }\end{array}$ \\
\hline 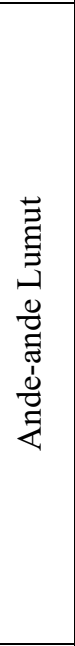 & $\begin{array}{l}\text { Panji } \\
\text { Asmarabangun } \\
\text { (the son of King } \\
\text { Jayengnegara) is } \\
\text { engaged to } \\
\text { Sekartaji (the } \\
\text { daughter of King } \\
\text { Jayengrana). They } \\
\text { live happily as a } \\
\text { married couple in } \\
\text { Jenggala. }\end{array}$ & $\begin{array}{l}\text { One day, the } \\
\text { Kingdom of } \\
\text { Jenggala is } \\
\text { attacked by an } \\
\text { enemy. Princess } \\
\text { Dewi Sekartaji } \\
\text { escapes from } \\
\text { the palace and } \\
\text { hides in a } \\
\text { village, } \\
\text { disguising } \\
\text { herself as } \\
\text { Kleting Kuning. }\end{array}$ & $\begin{array}{l}\text { After peace and } \\
\text { security reign } \\
\text { again in } \\
\text { Jenggala } \\
\text { Kingdom, the } \\
\text { Prince decides to } \\
\text { search for his } \\
\text { wife by } \\
\text { disguising } \\
\text { himself as Ande } \\
\text { Ande Lumut. }\end{array}$ & $\begin{array}{l}\text { Ande Ande } \\
\text { Lumut } \\
\text { announces a } \\
\text { contest for } \\
\text { girls to be his } \\
\text { wife. Kleting } \\
\text { Kuning wins } \\
\text { the contest. } \\
\text { Other girls do } \\
\text { not win } \\
\text { because they } \\
\text { allow } \\
\text { themselves to } \\
\text { be kissed by } \\
\text { cunning Yuyu } \\
\text { Kangkang. }\end{array}$ & $\begin{array}{l}\text { Finally, the } \\
\text { enamored } \\
\text { couple is } \\
\text { reunited and } \\
\text { they return to } \\
\text { the palace to } \\
\text { live happily } \\
\text { ever after. }\end{array}$ \\
\hline 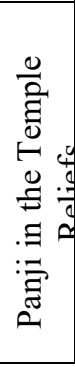 & $\begin{array}{l}\text { Yearning and } \\
\text { Separation: a man } \\
\text { and a woman are } \\
\text { sitting in a typical } \\
\text { sensual pose } \\
\text { yearning for love }\end{array}$ & $\begin{array}{l}\text { The journey of a } \\
\text { man with a hat } \\
\text { and his aides or } \\
\text { kadeyan - } \\
\text { Kertolo and } \\
\text { Jurudeh. }\end{array}$ & $\begin{array}{l}\text { The encounter } \\
\text { with a hermit. }\end{array}$ & $\begin{array}{l}\text { Crossing the } \\
\text { body of } \\
\text { water. }\end{array}$ & $\begin{array}{l}\text { The union of a } \\
\text { man's and a } \\
\text { woman's flesh } \\
\text { in an } \\
\text { intertwining } \\
\text { position } \\
\text { suggesting a } \\
\text { sexual } \\
\text { intercourse. }\end{array}$ \\
\hline
\end{tabular}

It can be seen clearly that the cycle of Todorov's narrative in Table 2 cannot fully explain the essence of Panji Story. Even though the five narrative units are fulfilled, the new equilibrium in the form of cycle cannot adequately explain the transformation of physical reality to the spiritual reality; from the sexual intercourse and union to the spiritual intercourse and union. Therefore, it is suggested that the narrative scheme of the Panji story be linear instead of cyclical. The new scheme can be seen in the following figure. 


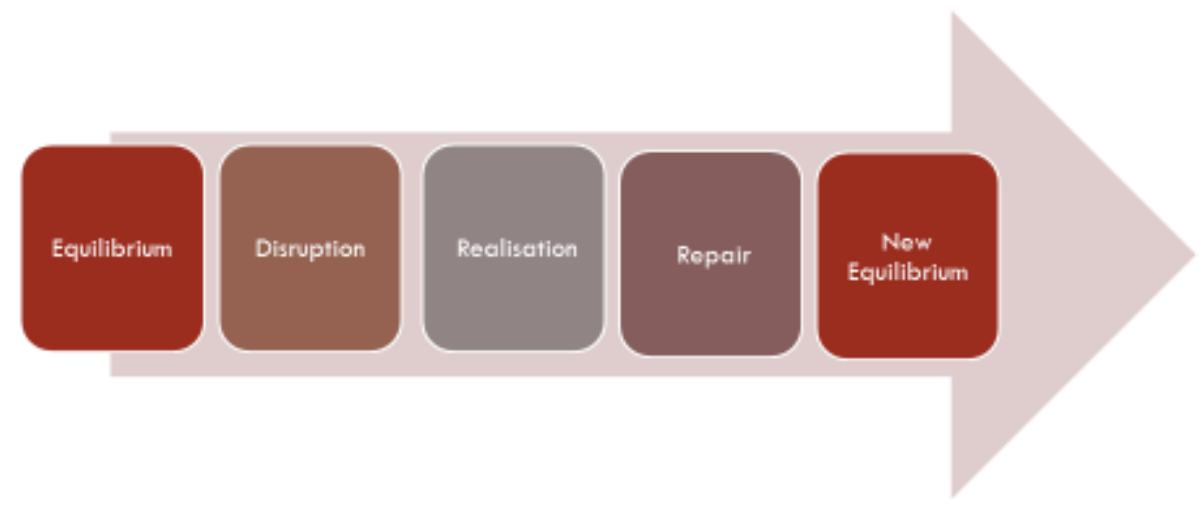

Figure 3 Narrative Structure of the Panji Story

One problem remains in the equilibrium stage in Todorov's narratology model. Using the narrative structure model as seen in Scheme 3, it can be concluded that the narrative story of Panji is not confined in the same physical circle. The Panji story is not a mere romantic love story. The Panji story actually represents human's constant conquest in understanding the origin of his life (sangkan paraning dumadi - the beginning of things) and in uniting with his Creator. It is a story of human's spiritual journey to the higher stage.

\section{Conclusion}

The Panji story is a very popular Indonesian narrative story as a part of a Panji Culture. The popularity of the Panji story is due to the fact that the stories are presented in various communication media, both spoken and written. The story shifts the narrative center from being a palace-centered esoteric stories to commoners-centered esoteric stories. The study of Todorov's narratology proves that the narrative sequences in the Panji story have covered the five stages of narrative development, namely equilibrium, disruption, realization, repair, and new equilibrium. However, the results of the study prove that the pattern of the narratology development of the Panji story is not circular but linear.

There are three layers of meaning in the Panji story. First, the Panji story reflects a Javanese romantic story describing love, faithfulness, and efforts. The Panji story teaches virtues of romantic relationship, namely faithfulness, sincerity to love, and efforts to win the heart of the loved one. Second, the Panji story symbolizes political agreement in uniting two historical kingdoms, Jenggala Kingdom and Daha Kingdom, by a marriage bond between Panji Asmarabangun from Jenggala and Putri Candrakirana from Daha Kingdom. This political agreement is an important aspect in maintaining peace and harmony. Kediri Kingdom is famous for the awakening in the classic literature. Some classic literary works written in the era of Kediri Kingdom were Kakawin Bharatayuddha, Hariwangsa, and Gatotkacasraya by Mpu Panuluh, Smaradahana by Mpu Dharmaja, and Prelambang Joyoboyo, Lubdhaka and Wrtasancaya by Mpu Tanakung (Kieven, 2014 b). In this context, it can be implied that Majapahit Kingdom also wanted peaceful and harmonious life by promoting the Panji story. Third, the Panji story containing tantric and spiritual symbols reveals the meaning 
of Panji's spiritual journey in understanding his origin and purpose of life or sangkan paraning dumadinya (see Taum, 2018). The third layer of meaning is actually the hidden allusion which becomes the main message of the Panji story.

\section{References}

Agung, P.W. (2018). Cerita Panji Masuk Dongeng Warisan Dunia. Suara Merdeka, 24 Februari 2018.

Kieven, L. (2014) (a), Menelusuri figur bertopi dalam relief candi zaman Majapahit. Pandangan baru terhadap fungsi religius Candi-Candi periode Jawa Timur abad ke-14 dan ke-15. Jakarta: EFEO / Kepustakaan Populer Gramedia.

Kieven, L. (2014) (b). Simbolisme Cerita Panji dalam Relief-Relief di Candi Zaman Majapahit dan Nilainya Pada Masa Kini. A seminar paper 'Cerita Panji Sebagai Warisan Budaya Dunia, Seminar Naskah Panji’ in Perpustakaan Nasional Republik Indonesia (Jakarta, 28 / 29 October 2014).

Kuntara, I. (1990). Kakawin arjunawiwaha. transformasi teks Jawa Kuno. Yogyakarta: Duta Wacana University Press

Nurcahyo, H, (2016). Memahami Budaya Panji. Surabaya: Pusat Konservasi Budaya Panji.

Prasetya, S. Hanggar, and Dana, I. 2014. Panji dalam berbagai tradisi nusantara. A Seminar Proceedings of Tokoh Panji Indonesia. Yogyakarta: FSP ISI Yogyakarta.

Richardson, J, (2017). Todorov's Narrative Theory. Downloaded from https://www.slideshare.net/Katrinabrookes/todorovs-narrative-theory24244633

Taum, Y. Y. (2011). Studi sastra lisan: Sejarah, teori, metode dan pendekatan disertai contoh penerapannya. Yogyakarta: Penerbit Lamalera.

Taum, Y. Y. (2018). Kajian Semiotika: Godlob Danarto dalam perspektif Teeuw. Yogyakarta: Sanata Dharma University Press.

Todorov, T. (1971). The Two Principles of Narratives. Diacritics 1(1), pp. 37-44. 